\title{
Characterizations on Mechanical Properties and In Vitro Bioactivity of Biomedical Ti-Nb-Zr-CPP Composites Fabricated by Spark Plasma Sintering
}

\author{
Zheng-Yuan He $\mathrm{He}^{1,2} \cdot$ Lei Zhang ${ }^{1,2} \cdot$ Wen-Rui Shan ${ }^{1,2}$. \\ Yu-Qin Zhang ${ }^{1,2,3} \cdot$ Ye-Hua Jiang ${ }^{1,2} \cdot$ Rong Zhou ${ }^{1,2}$. \\ Jun Tan ${ }^{1,2,4}$
}

Received: 2 June 2016/Revised: 13 July 2016/Published online: 22 September 2016

(C) The Chinese Society for Metals and Springer-Verlag Berlin Heidelberg 2016

\begin{abstract}
To alleviate the bio-inert of Ti alloys as hard tissue implants, $\mathrm{Ti}-35 \mathrm{Nb}-7 \mathrm{Zr}-x \mathrm{CPP}$ (calcium pyrophosphate, $x=5,10,15,20 \mathrm{wt} \%$ ) composites were prepared by mechanical alloying (MA) and following spark plasma sintering (SPS). Mechanical behaviours and in vitro bioactivity of these composites were investigated systematically. Results showed that the composites consisted of $\beta$-Ti matrix, $\alpha$-Ti, and metal-ceramic phases such as $\mathrm{CaO}, \mathrm{CaTiO}_{3}, \mathrm{CaZrO}_{3}$, and $\mathrm{Ti}_{x} \mathrm{P}_{y}$. With increasing CPP content, the composites had higher strength (over $1500 \mathrm{MPa}$ ) and higher elastic modulus, but suffered almost zero plastic deformation together with lower relative density. When the CPP contents were 5 and $10 \mathrm{wt} \%$, the compressive elastic moduli were 44 and $48 \mathrm{GPa}$, respectively, which were close to those of natural bones. However, the compressive elastic modulus of the composites increased significantly when CPP contents exceed $10 \mathrm{wt} \%$, thus deteriorating the mechanical compatibility of the composites owing to more $\alpha$-Ti and metal-ceramic phases. Besides, the surface of Ti-35Nb-7Zr-10CPP composite was deposited as a homogeneous apatite layer during soaking in simulated body fluid (SBF). It indicates a good bioactivity between the implant materials and living bones.
\end{abstract}

KEY WORDS: Composites; Spark plasma sintering; Microstructure; Mechanical behaviours; Bioactivity

Available online at http://link.springer.com/journal/40195

Yu-Qin Zhang

zyqkust@163.com

1 School of Materials Science and Engineering, Kunming University of Science and Technology, Kunming 650093, China

2 National-local Joint Engineering Laboratory of Metal Advanced Solidification Forming and Equipment Technology, Kunming 650093, China

3 Engineering Technology Research Center of Titanium Products and Application of Yunnan Province, Kunming 650093, China

4 IFW Dresden, Institute for Complex Materials, P.O. Box 2701 16, 01171 Dresden, Germany

\section{Introduction}

Pure Ti and $\mathrm{Ti}-\mathrm{Al}-\mathrm{V}$ alloys with extra low interstitial (ELI) have been regarded as suitable structural biomaterials and are currently widely used for replacing failed hard tissues, such as artificial hip, shoulder, knee joints, and dental implants because of their unique combination of high specific strength, high corrosion resistance, and biocompatibility [1-3]. However, Ti-6Al-4V alloy could release harmful accumulation of $\mathrm{Al}$ and $\mathrm{V}$ ions in the host [4]. In addition, the poor shear strength and high elastic modulus of $\mathrm{Ti}$ and Ti-based alloys might result in stress shielding and implant failure. Therefore, the development of titanium alloys composed of non-toxic 
and non-allergenic elements combined with appropriate mechanical properties is critical. $\mathrm{Ti}-\mathrm{Nb}-\mathrm{Zr}$ alloys have attracted considerable attentions in recent years owing to their combination of low elastic modulus and high compressive strength [5-7]. Furthermore, tissue reaction studies have identified that $\mathrm{Ti}, \mathrm{Nb}$, and $\mathrm{Zr}$ elements are non-toxic and non-allergenic and will not cause any dangerous reactions in the human body $[8,9]$. The elastic modulus of $\mathrm{Ti}-35 \mathrm{Nb}-7 \mathrm{Zr}$ alloy is about $54 \mathrm{GPa}$ [10], and this value is much closer to that of human bones. So the $\mathrm{Ti}-\mathrm{Nb}-\mathrm{Zr}$ alloys have been regarded as one of the most promising biomaterials. However, almost all Ti alloys including $\mathrm{Ti}-35 \mathrm{Nb}-7 \mathrm{Zr}$ alloy are bio-inert and thus are difficult to bond directly to living bone unlike bioactive ceramics.

Calcium pyrophosphate (CPP) has a similar composition and microstructure to human bones. Therefore, it is biocompatible with hard tissues and exhibits good bioactivity. Nevertheless, CPP has so poor mechanical properties that it cannot be solely used in heavily loaded or large areas. Thus, it has triggered much interest in recent years to fabricate Ti-based composites combining the advantages of $\mathrm{CPP}$ and $\beta$-type titanium alloys [11]. It is reported that the biocompatibility of $\mathrm{Ti}-35 \mathrm{Nb}-7 \mathrm{Zr}$ alloy can be improved by adding CPP by spark plasma sintering (SPS) technique. However, the influence mechanism on mechanical properties and bioactivity of such composites is not well documented.

In the present work, $\mathrm{Ti}-35 \mathrm{Nb}-7 \mathrm{Zr}-x \mathrm{CPP}$ composites were fabricated by SPS. The relative density and microstructure of sintered composites with different CPP contents were investigated to analyse the influence of reaction products on their mechanical properties. The bioactivity of composites was evaluated by immersion test in simulated body fluid (SBF), which helped us to understand the effects of matrix and reaction products on apatiteforming propensity of such composites.

\section{Experimental}

Elemental powders of $\mathrm{Ti}(99.5 \%, 25 \mu \mathrm{m}), \mathrm{Nb}(99.95 \%$, $10.5 \mu \mathrm{m}), \mathrm{Zr}(99.5 \%, 25 \mu \mathrm{m})$, and pure nano CPP powders were used as raw materials. The powders were prepared according to the nominal composition of $\mathrm{Ti}-35 \mathrm{Nb}-7 \mathrm{Zr}$ alloy and $\mathrm{Ti}-35 \mathrm{Nb}-7 \mathrm{Zr}-x \mathrm{CPP}$ composites $(x=5,10,15$, $20 \mathrm{wt} \%)$. The milling process was conducted in a mill/ mixer machine (XQM-4, China) with stainless steel containers and balls (the ratio of ball to powders is 3:1) under a vacuum atmosphere for $10 \mathrm{~h}$. During the milling and mixing process, anhydrous alcohol was used to maintain the balance between cold welding and fracture of the powders and to avoid cross-contamination. The blended powders were then dried and compacted in graphite moulds (outside diameter: $30 \mathrm{~mm}$, inside diameter: $20 \mathrm{~mm}$, and height: $40 \mathrm{~mm}$ ). The schematic of the equipment used for SPS is shown in Fig. 1. The green compacts were sintered by SPS system (SPS-515S, Syntex Inc, Japan) at $1000{ }^{\circ} \mathrm{C}$ for $5 \mathrm{~min}$. The heating rate was $100{ }^{\circ} \mathrm{C} \mathrm{min}^{-1}$. The sintered sample was cooled inside the furnace to room temperature. The temperature was measured using a pyrometer focused on the measurement hole of the graphite die (see Fig. 1). The sintering was applied in a vacuum chamber at 5-10 $\mathrm{Pa}$ and a uniaxial pressure of $40 \mathrm{MPa}$.

The phases of the blended powders and the sintered specimens were investigated by X-ray diffraction (XRD, Bruker D8 Advance, Germany) with $\mathrm{Cu} K \alpha$ radiation within the range of $20^{\circ}-80^{\circ}$. The morphology of the sintered specimens was observed by scanning electron microscopy (SEM, FEI, QUANTA 600, Netherlands). The densities of the sintered specimens were calculated by using Archimedes' method. The mechanical properties of the composites were evaluated using a universal testing machine (Shimadzu, AG-X $100 \mathrm{KN}$, Japan). According to Chinese Standard GB/T 7314-2005, the specimens were processed into $\Phi 4 \mathrm{~mm} \times 10 \mathrm{~mm}$ and $\Phi 2 \mathrm{~mm} \times 10 \mathrm{~mm}$ for measuring compressive strength and compressive

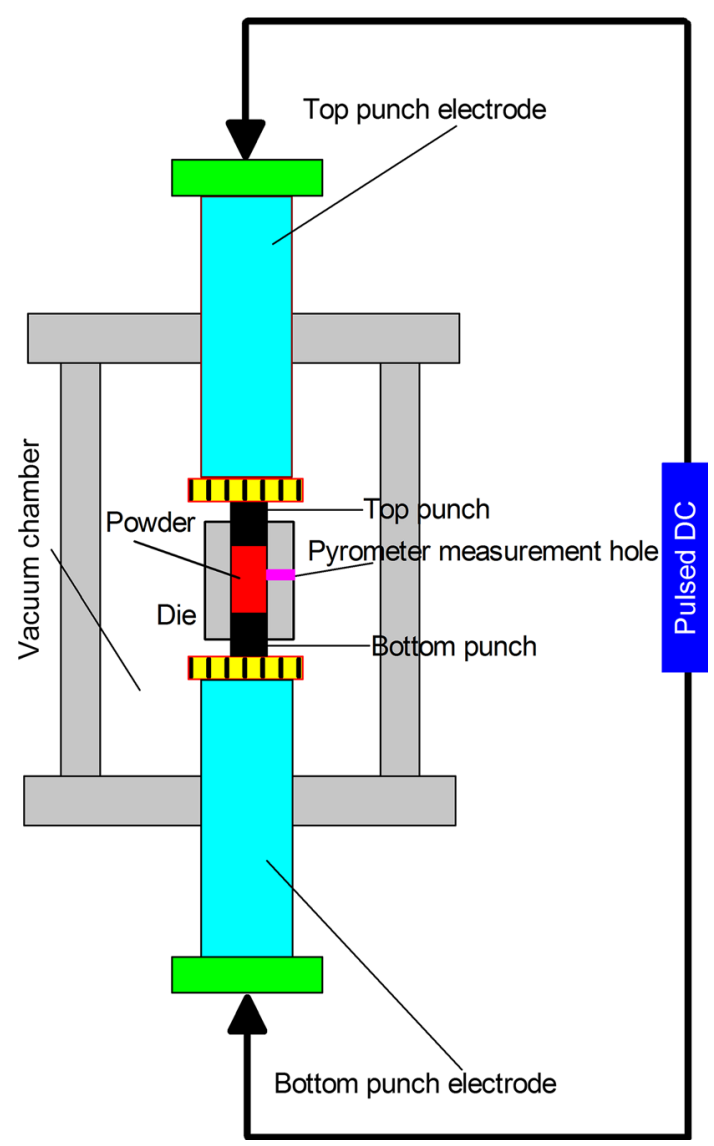

Fig. 1 Schematic of SPS 
elastic modulus, respectively. The cross-head displacement rate in these tests was $1 \mathrm{~mm} \mathrm{~min}{ }^{-1}$.

The bioactivity of the composites was assessed by soaking in SBF. The $\mathrm{SBF}$ was prepared by dissolving reagent grade $\mathrm{NaCl}, \mathrm{NaHCO}_{3}, \mathrm{KCl}, \mathrm{K}_{2} \mathrm{HPO}_{4} \cdot 3 \mathrm{H}_{2} \mathrm{O}, \mathrm{MgCl}_{2} \cdot 6 \mathrm{H}_{2} \mathrm{O}, \mathrm{CaCl}_{2}$, and $\mathrm{Na}_{2} \mathrm{SO}_{4}$ into double-distilled water and buffering at $\mathrm{pH}$ 7.4 at $36.5{ }^{\circ} \mathrm{C}$ with tris-hydroxymethylamino-methane and hydrochloric acid [12]. Before testing, all specimens were polished and then cleaned in deionised water and an ultrasonic bath for $5 \mathrm{~min}$. The specimens were soaked in SBF solution for 7 days. The solution was refreshed every $24 \mathrm{~h}$ to maintain a $\mathrm{pH}$ value of 7.4 , and the temperature was maintained at $37{ }^{\circ} \mathrm{C}$ during soaking. The specimens, after SBF immersion, were dried in a vacuum desiccator to remove any entrapped water molecules. After testing, the surface morphology was observed by SEM (SPM-S3400 N: Japan).

\section{Results and Discussion}

\subsection{Mechanical Alloying Powders}

Figure 2 shows the XRD patterns of $\mathrm{Ti}-35 \mathrm{Nb}-7 \mathrm{Zr}-x \mathrm{CPP}$ $(x=0,10$ and $20 \mathrm{wt} \%)$ powders. The XRD patterns of the powders fabricated by mechanical alloying (MA) for $10 \mathrm{~h}$ indicate that there are $\beta-\mathrm{Ti}, \alpha-\mathrm{Ti}, \mathrm{Zr}$, and CPP. It means that certain reactions occurred during milling. The $\alpha-\mathrm{Ti}$ phases were transformed into $\beta$-Ti phases due to the $\beta$-Ti stability-inducing elements ( $\mathrm{Nb}$ and $\mathrm{Zr}$ ) during the milling process, which is in agreement with that observed by Wang et al. [13]. However, when the CPP was added, the transformation of $\alpha$-Ti to $\beta$-Ti could be depressed. So the peaks of $\alpha$-Ti were boosted, while those of $\beta$-Ti were weakened

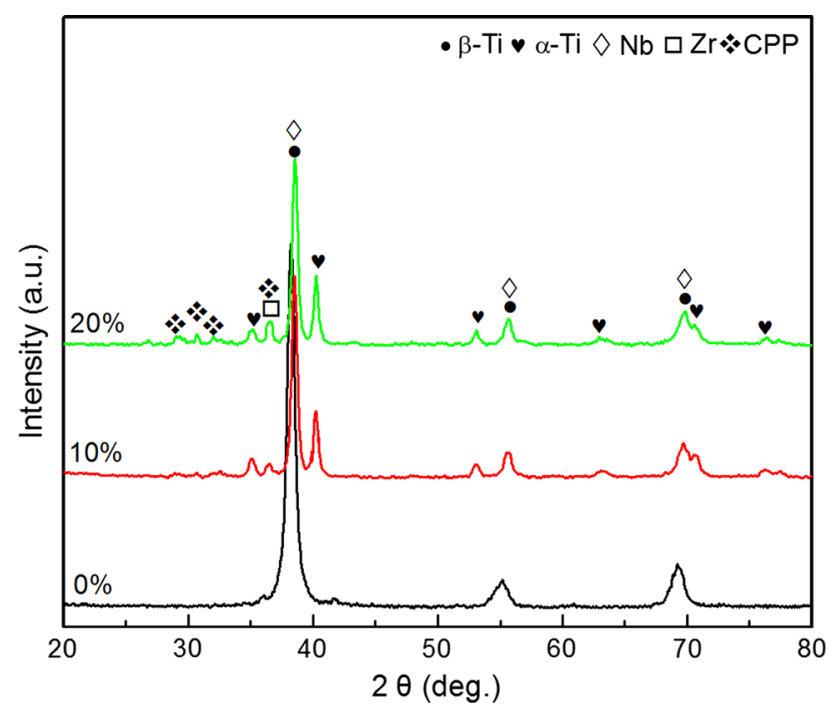

Fig. 2 XRD patterns of $\mathrm{Ti}-35 \mathrm{Nb}-7 \mathrm{Zr}-x \mathrm{CPP}(x=0,10,20 \mathrm{wt} \%)$ powders with increasing CPP content. However, the CPP powders were almost not decomposed during milling.

\subsection{Relative Density}

Figure 3 shows the relative density of sintered $\mathrm{Ti}-35 \mathrm{Nb}-$ $7 \mathrm{Zr}$ alloy and $\mathrm{Ti}-35 \mathrm{Nb}-7 \mathrm{Zr}-x \mathrm{CPP}$ composites with different CPP contents. The relative density of sintered Ti$35 \mathrm{Nb}-7 \mathrm{Zr}-x \mathrm{CPP}$ composites decreases from 98.9 to $96.1 \%$ with increasing CPP content, which are lower than that of $\mathrm{Ti}-35 \mathrm{Nb}-7 \mathrm{Zr}$ alloy. It could be deduced that the CPP ceramic decreased the SPS sintering ability and thus increased the number of flaws in the sintered composites, which led to high porosity in the specimens. These results suggested that too much CPP impaired the densification of $\mathrm{Ti}-35 \mathrm{Nb}-7 \mathrm{Zr}-x \mathrm{CPP}$ composites. The trend in densification was consistent with that investigated by Woo et al. [11]. However, the densification was higher because of increasing milling time $(10 \mathrm{~h})$ leading to finer particles, thus affecting densification and sintering ability.

\subsection{Mechanical Behaviours}

The mechanical behaviour of the sintered specimens was investigated by compressive testing as shown in Fig. 4. It can be seen that the $\mathrm{Ti}-35 \mathrm{Nb}-7 \mathrm{Zr}$ alloy has a high yield strength of about $1300 \mathrm{MPa}$ combined with a large plastic deformation. When the CPP content is $5 \mathrm{wt} \%$, the yield strength increases over $1700 \mathrm{MPa}$. However, the plastic strain decreases significantly. With increasing CPP content, the composites are brittle when the CPP content exceeds $5 \mathrm{wt} \%$.

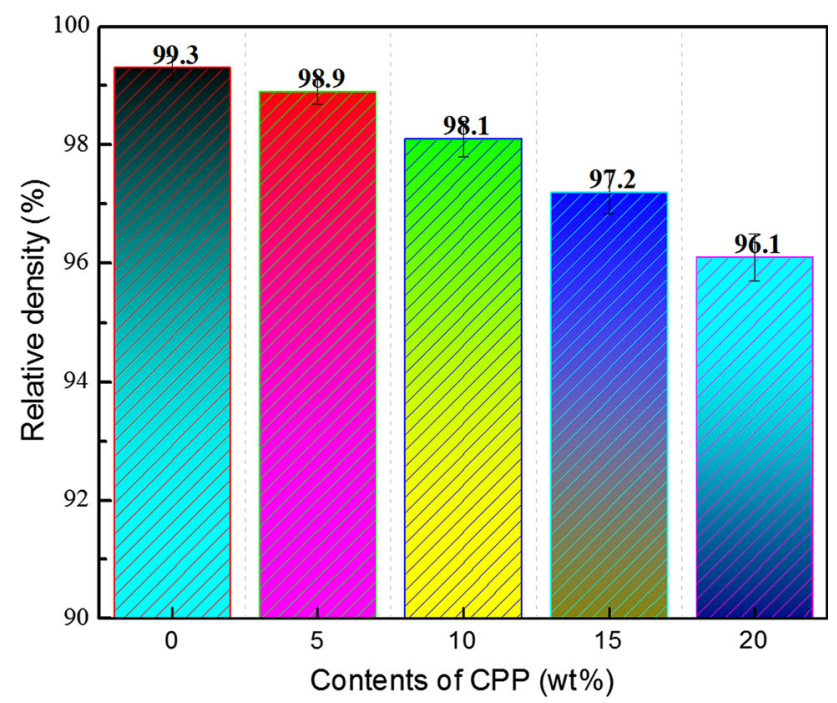

Fig. 3 Relative density of the sintered $\mathrm{Ti}-35 \mathrm{Nb}-7 \mathrm{Zr}$ alloy and $\mathrm{Ti}-$ $35 \mathrm{Nb}-7 \mathrm{Zr}-x \mathrm{CPP}$ composites $(x=5,10,15,20 \mathrm{wt} \%)$ at $1000{ }^{\circ} \mathrm{C}$ 


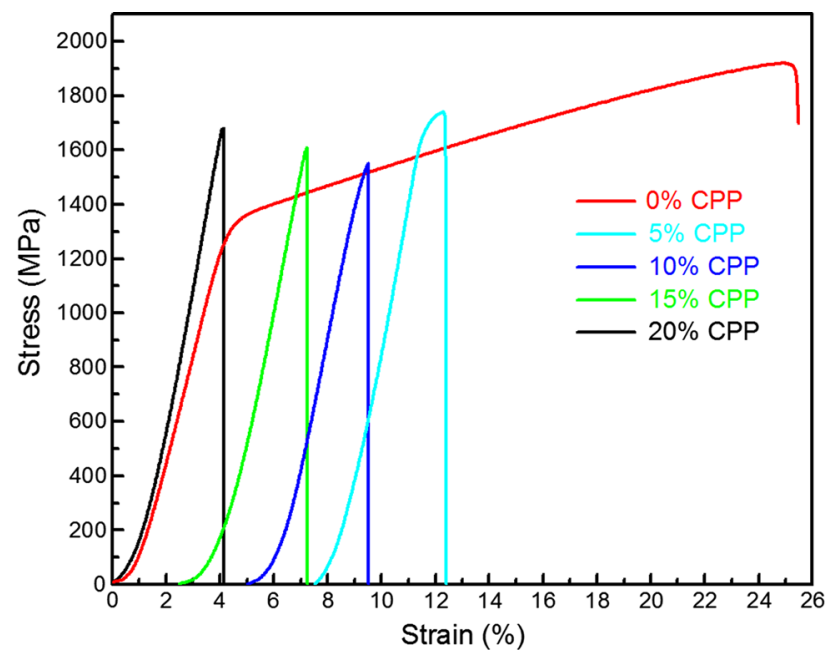

Fig. 4 Compression stress-strain curves of Ti-35Nb-7Zr alloy and $\mathrm{Ti}-35 \mathrm{Nb}-7 \mathrm{Zr}-x \mathrm{CPP}$ composites $(x=5,10,15,20 \mathrm{wt} \%)$

The effects of CPP content on the compressive strength and compressive elastic modulus of sintered $\mathrm{Ti}-35 \mathrm{Nb}-7 \mathrm{Zr}$ alloy and $\mathrm{Ti}-35 \mathrm{Nb}-7 \mathrm{Zr}-x \mathrm{CPP}$ composites are shown in Fig. 5. The compressive strength of Ti-35Nb-7Zr alloy is $1923 \mathrm{MPa}$, but the compressive strength of the Ti-35Nb$7 \mathrm{Zr}-x \mathrm{CPP}$ composites decreases to 1700 and $1525 \mathrm{MPa}$ when CPP contents are 5 and $10 \mathrm{wt} \%$, respectively. However, when the CPP content is between 15 and $20 \mathrm{wt} \%$, the compressive strength of the sintered composites increases to 1581 and $1680 \mathrm{MPa}$, respectively. It should be mentioned that the strength of $\mathrm{Ti}-35 \mathrm{Nb}-7 \mathrm{Zr}-$ $x \mathrm{CPP}$ composites is higher than that of ultrafine-grained $\mathrm{Ti}$ (1100 MPa) [14], thus meeting the requirements of biomedical implant design. Contrary to the tendency of the strength, the compressive elastic modulus of $\mathrm{Ti}-35 \mathrm{Nb}-$ $7 \mathrm{Zr}-x \mathrm{CPP}$ composites consistently increases from 42 to 66

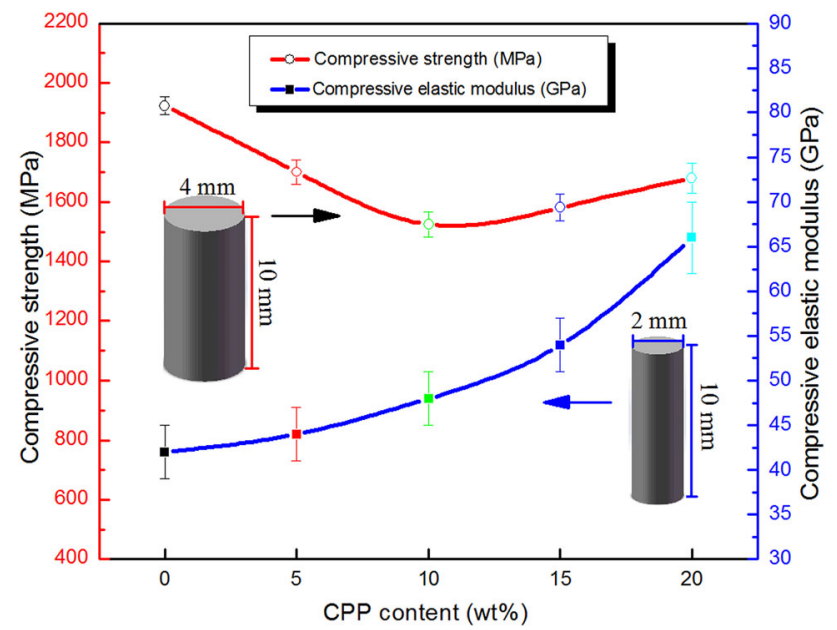

Fig. 5 Compressive elastic modulus and compressive strength of $\mathrm{Ti}-$ $35 \mathrm{Nb}-7 \mathrm{Zr}$ alloy and $\mathrm{Ti}-35 \mathrm{Nb}-7 \mathrm{Zr}-x \mathrm{CPP}$ composites $(x=5,10,15$, $20 \mathrm{wt} \%)$
GPa with increasing CPP content. However, the elastic modulus of the sintered specimens significantly increases when the CPP content exceeds $10 \mathrm{wt} \%$, which could result in stress shielding when used as implant materials. The elastic modulus of composites with 5 and $10 \mathrm{wt} \%$ CPP varies from 44 to $48 \mathrm{GPa}$, which is slightly higher than that of the original $\mathrm{Ti}-35 \mathrm{Nb}-7 \mathrm{Zr}$ alloy ( $42 \mathrm{GPa}$ ), and is close to that of natural bones (10-30 GPa), indicating good mechanical compatibility.

Figure 6 shows the XRD patterns of the sintered specimens. The $\alpha$-Ti still remains in all sintered composites except for $\mathrm{Ti}-35 \mathrm{Nb}-7 \mathrm{Zr}$ alloy. However, the $\alpha$-Ti peaks emerge with increasing CPP content. When the CPP contents are 15 and $20 \mathrm{wt} \%$, the peaks of $\alpha$-Ti phase become stronger (Fig. 6d, e). This was because more CPP powders were present around the Ti powders and $\beta$-Ti stabilization elements (e.g. $\mathrm{Nb}$ and $\mathrm{Zr}$ ) because of the lower intensity of diffusion among the $\mathrm{Ti}, \mathrm{Nb}$, and $\mathrm{Zr}$ during sintering. Thus, the transformation from $\alpha$ to $\beta$ phase could be hindered. In other words, the amount of $\alpha$-Ti phase increased due to the hindering effects of CPP during the process of diffusion for $\beta$-Ti stabilization elements. Furthermore, the interstitial $\alpha$ stabilizer (e.g. O) decomposed from CPP might hinder the transformation from $\alpha$ to $\beta$ phase $[15,16]$. As a matter of fact, $\alpha$-Ti could improve the elastic modulus of titanium alloy. Therefore, the content of $\alpha$-Ti phases in $\mathrm{Ti}-35 \mathrm{Nb}-$ $7 \mathrm{Zr}-x \mathrm{CPP}$ composites increased, leading to the increased compressive elastic modulus from 44 to $66 \mathrm{GPa}$.

However, the dominated phase of sintered $\mathrm{Ti}-35 \mathrm{Nb}-$ $7 \mathrm{Zr}-x \mathrm{CPP}$ composites was $\beta$ - $\mathrm{Ti}$, which was known to decrease Young's modulus of Ti alloys. In addition, the $\mathrm{XRD}$ patterns show metal-ceramic phases such as $\mathrm{CaO}$,

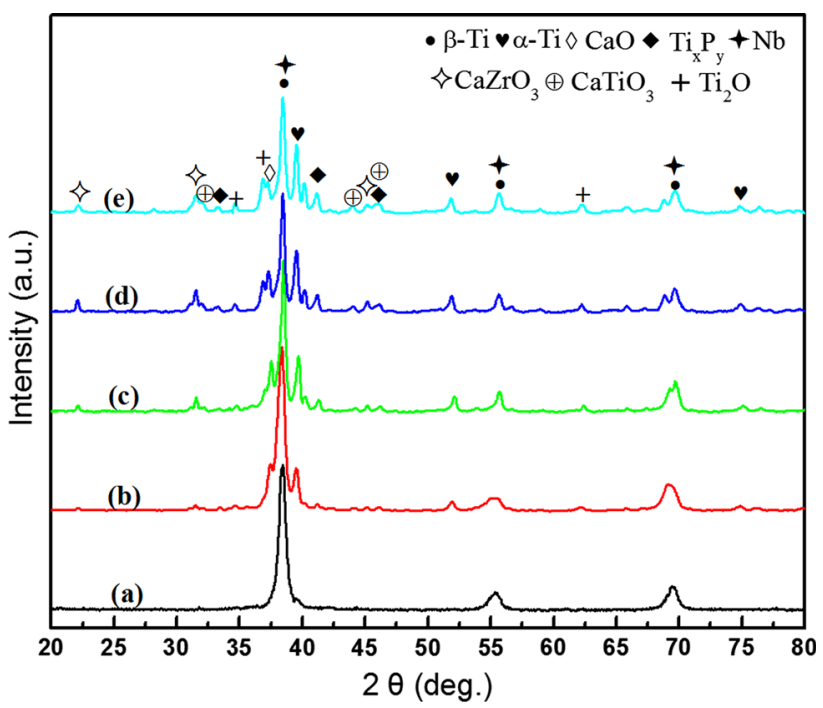

Fig. $6 \mathrm{XRD}$ patterns of a $\mathrm{Ti}-35 \mathrm{Nb}-7 \mathrm{Zr}$ alloy, b $\mathrm{Ti}-35 \mathrm{Nb}-7 \mathrm{Zr}-$ $5 \mathrm{CPP}, \mathbf{c} \mathrm{Ti}-35 \mathrm{Nb}-7 \mathrm{Zr}-10 \mathrm{CPP}, \mathbf{d} \mathrm{Ti}-35 \mathrm{Nb}-7 \mathrm{Zr}-15 \mathrm{CPP}$, e $\mathrm{Ti}-35 \mathrm{Nb}-$ $7 \mathrm{Zr}-20 \mathrm{CPP}$ 
$\mathrm{CaTiO}_{3}, \mathrm{CaZrO}_{3}$, and $\mathrm{Ti}_{x} \mathrm{P}_{y}$, which were formed during the sintering process. The sintering reaction could be expressed by Eq. (1) [11], Eq. (2), and Eq. (3) [17]:

$$
\begin{aligned}
& \mathrm{Ti}+\mathrm{Ca}_{2} \mathrm{P}_{2} \mathrm{O}_{7} \rightarrow \mathrm{Ti}_{2} \mathrm{O}+\mathrm{CaO}+\mathrm{CaTiO}_{3}+\mathrm{Ti}_{x} \mathrm{P}_{y}, \\
& \mathrm{Zr}+\mathrm{O} \rightarrow \mathrm{ZrO}_{2}, \\
& \mathrm{ZrO}_{2}+\mathrm{CaO} \rightarrow \mathrm{CaZrO}_{3} .
\end{aligned}
$$

These results suggested that the phase composition of sintered $\mathrm{Ti}-35 \mathrm{Nb}-7 \mathrm{Zr}-\mathrm{CPP}$ composites was affected by CPP content. Too much CPP could not only reduce the stability of $\beta$-Ti but also increase the number of metalceramic phases due to the reaction between the metal elements and CPP. Thus, the densification of the composites decreased, which was harmful to their mechanical properties, and it was, therefore, necessary to control the CPP content to within an optimum range.

Figure 7 shows the SEM-BSE (backscattered electron) images of sintered $\mathrm{Ti}-35 \mathrm{Nb}-7 \mathrm{Zr}$ alloy and $\mathrm{Ti}-35 \mathrm{Nb}-7 \mathrm{Zr}-$ $x$ CPP composites with different CPP contents. One can see that the $\mathrm{Ti}-35 \mathrm{Nb}-7 \mathrm{Zr}$ alloy is mainly composed of $\mathrm{Ti}-$ and Nb-rich regions: these regions appear to be dark grey or grey and white, respectively (Fig. 7a). When $5 \mathrm{wt} \%$ CPP is added, the grain sizes in $\mathrm{Ti}-$ and $\mathrm{Nb}$-rich regions decrease, and small holes appear. Acicular phases can be observed around the grain boundaries (see red arrows in Fig. 7b, c). More CPP addition introduced more holes and smaller grains as shown in Fig. 7d, e. When the CPP content exceeds $10 \mathrm{wt} \%$, a net-like structure can be seen in the Ti matrix (Fig. 7e) and in a locally magnified view (Fig. 7f), much finer grains appear. EDS spectra of points $\mathrm{A}, \mathrm{B}$, and $\mathrm{C}$ in Fig. 7 are shown in Fig. 8. Point $\mathrm{A}$ is located in a porous area which mainly consists of $\mathrm{Ca}, \mathrm{P}$, and some metal elements. Moreover, the acicular phases, as seen in Fig. 7c, are composed of $\mathrm{Ti}, \mathrm{Ca}, \mathrm{P}$, and $\mathrm{O}$. This demonstrates that some $\mathrm{Ca}$ and $\mathrm{P}$ gather in holes, and the acicular phases with high $\mathrm{P}$ and $\mathrm{Ca}$ concentrations begin to grow in the Ti matrix when the CPP content is either 5 or $10 \mathrm{wt} \%$. This phenomenon is accelerated due to the CPP content exceeding $10 \mathrm{wt} \%$, which results in net-like phase growth in the Ti matrix. By EDS analysis of point $\mathrm{C}$, shown in Fig. 8, the net-like phases consist of $\mathrm{Ti}, \mathrm{Nb}, \mathrm{Zr}, \mathrm{Ca}, \mathrm{P}$, and $\mathrm{O}$.

The number of tiny holes in the composites increased due to the difference in thermal expansion coefficient between the ceramic and the metal phases. Thus, the ratio of pores increased with increasing CPP content, causing a reduction in relative density, as described in Fig. 3. Meanwhile, the holes would be beneficial for the induction of osteocyte growth [18]. Besides, $\mathrm{Ca}$ and $\mathrm{P}$ were mainly distributed around the holes or substrate, which would further induce osteocyte growth, as is well known that $\mathrm{Ca}$ and $\mathrm{P}$ are the main elemental constituents of CPP. A certain $\mathrm{Ca}$ and $\mathrm{P}$ content would improve the bioactivity of $\mathrm{Ti}$ alloys. However, more than $10 \mathrm{wt} \%$ CPP addition would
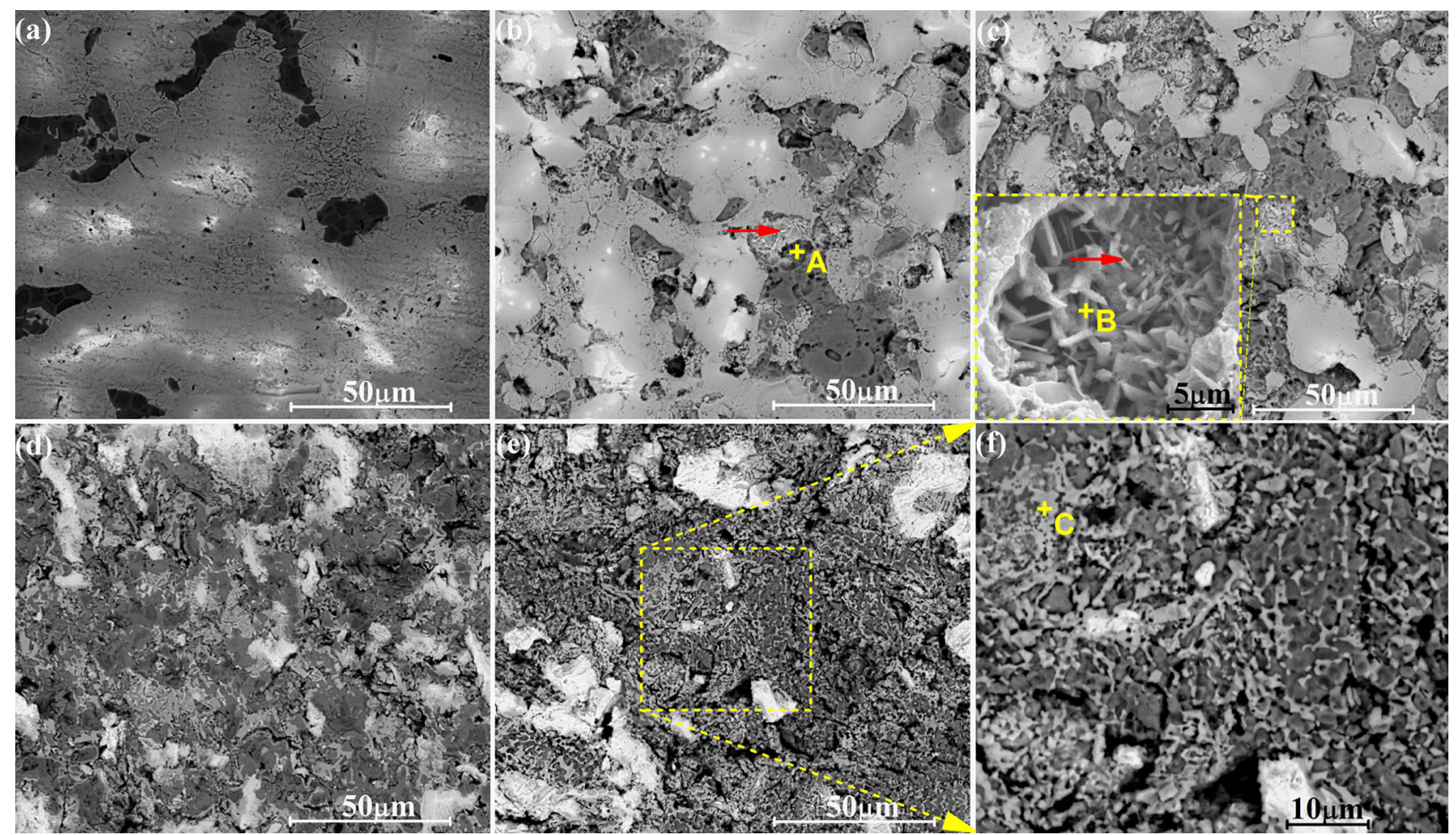

Fig. 7 SEM-BSE images of a Ti-35Nb-7Zr alloy, b Ti-35Nb-7Zr-5CPP, $\mathbf{c}$ Ti-35Nb-7Zr-10CPP, d Ti-35Nb-7Zr-15CPP, e, f Ti-35Nb-7Zr20CPP 

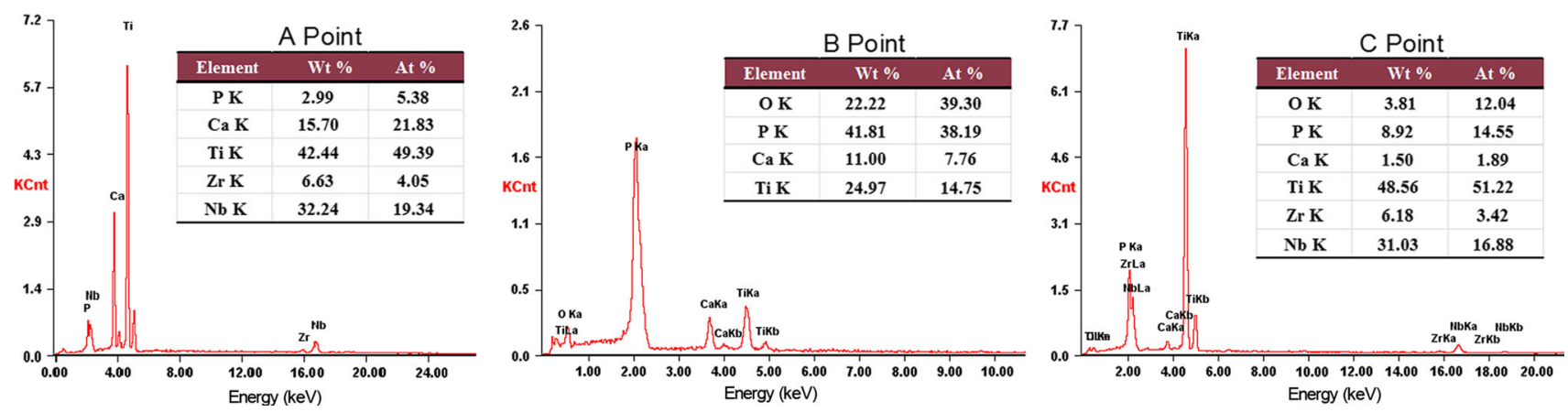

Fig. 8 EDS spectra of points $A, B, C$ in Fig. 7

lead to the incorporation and diffusion of the bio-ceramic elements into the Ti matrix, as shown in Fig. 7d-f. This affected the mechanical properties of the composites: the finer grains and metal-ceramic phases increased the compressive strength, but the compressive elastic modulus increased mainly due to the hard phases, such as $\mathrm{CaO}$, $\mathrm{CaZrO}_{3}, \mathrm{CaTiO}_{3}$, and so on.

During the SPS process, the powders of $\mathrm{Ti}-\mathrm{Nb}-\mathrm{Zr}$, without CPP, were charged with pulsed current, and the high temperature led to melting and evaporation among the particles as the powders had good conductivity. Under axial pressure, the powders were rapidly fused together by SPS. Because of the presence of elemental $\mathrm{Nb}$ and $\mathrm{Ti}$, largegrained $\beta$-Ti phases formed. When the CPP was added to the Ti alloy, the sintering mechanism could be interpreted as shown in Fig. 9. With increasing CPP content, the electrical conductivity of the powders decreased, so that the evaporation and melting on the surface of the particles diminished in intensity. Pulsed current in the subsequent sintering process could not directly penetrate the specimens, which were sintered by heating of the graphite mould and heat exchange between metal elements. The new phases formed through the reaction between $\mathrm{CPP}$ and $\mathrm{Ti}$, and impeded the formation of continuous $\beta$-Ti zones, then weakened the stability and reinforcement effect of $\mathrm{Nb}$ and $\mathrm{Zr}$ in $\beta$-Ti phases, and thus increased the amount of residual $\alpha$-Ti phases.

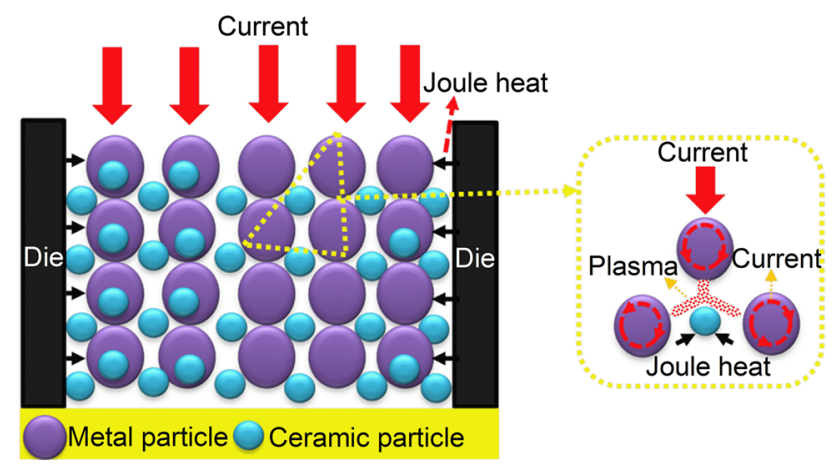

Fig. 9 Sintering mechanism of $\mathrm{Ti}-35 \mathrm{Nb}-7 \mathrm{Zr}-x \mathrm{CPP}$ powders during SPS process

\subsection{In Vitro Bioactivity}

Figure 10 shows the surface morphologies and phase composition of $\mathrm{Ti}-35 \mathrm{Nb}-7 \mathrm{Zr}$ alloy and $\mathrm{Ti}-35 \mathrm{Nb}-7 \mathrm{Zr}-10 \mathrm{CPP}$ composite after 7-day immersion in SBF at $37{ }^{\circ} \mathrm{C}$. The Ti$35 \mathrm{Nb}-7 \mathrm{Zr}$ alloy, expect for a few bright particles observed randomly on the surface, exhibits no growth of apatite layers after immersion for 7 days as shown in Fig. 10a. A magnified view of a bright particle, grown on the grain boundary of the Ti matrix, is shown in Fig. 10b. However, Ti-35Nb-7Zr-10CPP composite is homogeneously covered by a dune-like apatite layer, indicated in Fig. 10c, d, which changes the original surface morphology of composite completely. A typical magnified view of the area surrounding the tip of the large apatite particles (Fig. 10d) shows globular particles covering the entire surface of the composite and forming a layer thereon. The EDS analysis of point $\mathrm{A}$ shows high intensities of $\mathrm{Ca}$ and $\mathrm{P}$ with a $\mathrm{Ca} / \mathrm{P}$ atom ratio of 1.59 (Fig. 10e), which is close to the ratio of hydroxyapatite (1.67). The bone-like apatite layer has a structural form like that of hydroxyapatite, in which case this epitaxy would facilitate, without any external stimulant, osseointegration between the implant and human bone.

This phenomenon could be associated with $\mathrm{Ca}$ and $\mathrm{P}$ ionic dissolution of metal-ceramic phases in the composite $[19,20]$. Both $\mathrm{Ca}$ and $\mathrm{P}$ ions dissolved on the local area of the composite surface, which induced ions such as $\mathrm{Ca}^{2+}, \mathrm{OH}^{-}, \mathrm{PO}_{4}^{3-}$, and $\mathrm{HPO}_{4}^{2-}$ to deposit by electrostatic incorporation, as indicated in Fig. 11. This phenomenon boosted local supersaturation of $\mathrm{Ca}$ and $\mathrm{P}$ ions, inducing the nucleation of bone-like apatite crystals. Besides, the tiny holes formed with the addition of CPP, which made the boundary between each tiny hole and the Ti matrix be a potential nucleation site. The boundary was an energy concentration area; it could, therefore, provide the power for the nucleation and growth of bone-like apatite, which was a key method for the formation of the apatite particles on $\mathrm{Ti}-35 \mathrm{Nb}-$ $7 \mathrm{Zr}$ alloy surface during soaking. The surface of $\mathrm{Ti}-35 \mathrm{Nb}-7 \mathrm{Zr}$ alloy, however, had limited boundaries and could not release $\mathrm{Ca}$ and $\mathrm{P}$ ions to induce the formation of numerous bone-like apatite crystals, which is reflected in Fig. 10a, b. Furthermore, the Ti suboxides could be hydrated to form $\mathrm{Ti}-\mathrm{OH}$ groups on the 

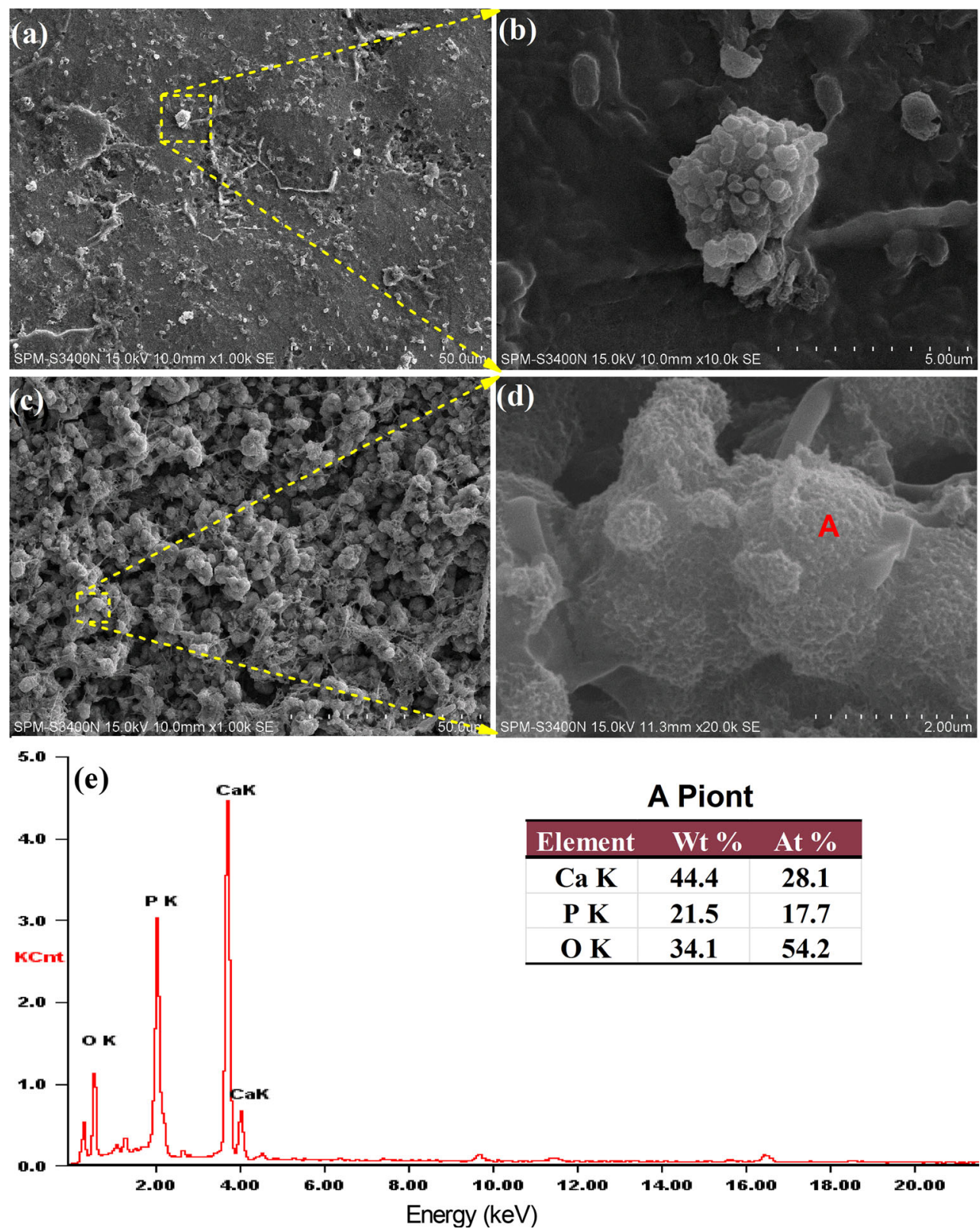

Fig. 10 Surface morphologies of samples after 7-day immersion in $\mathrm{SBF}$ at $37{ }^{\circ} \mathrm{C}$ : a, b $\mathrm{Ti}-35 \mathrm{Nb}-7 \mathrm{Zr}$ alloy, c, d $\mathrm{Ti}-35 \mathrm{Nb}-7 \mathrm{Zr}-10 \mathrm{CPP}$ composite, e EDS of an apatite particle

composite surface in the SBF according to the Eq. (4) [21], The Ti-OH groups could facilitate the apatite formation in the SBF by electrostatic potential interaction [22]. Thus, the surface of composites, with CPP addition, soaking in SBF was beneficial to the nucleation of bone-like apatite. Once nucleation completed, the growth would proceed spontaneously. Numerous bone-like apatite particles developed to form a homogeneous, dense layer on the surface of the $\mathrm{Ti}-35 \mathrm{Nb}-7 \mathrm{Zr}-10 \mathrm{CPP}$ composite after SBF immersion.

$2 \mathrm{Ti}_{x} \mathrm{O}+x \mathrm{H}_{2} \mathrm{O} \rightarrow \mathrm{Ti}-\mathrm{OH}$.

It is reported that a bone-like apatite layer precipitates on the surface of bioactive materials in the human body, which plays an essential role in forming the chemical bond between the bioactive material and living bone [23, 24]. Hence, the $\mathrm{Ti}-35 \mathrm{Nb}-7 \mathrm{Zr}-x \mathrm{CPP}$ composite has a better bioactivity than that of the $\mathrm{Ti}-35 \mathrm{Nb}-7 \mathrm{Zr}$ alloy without $\mathrm{CPP}$.

\section{Conclusions}

In this work, biomedical composites of $\mathrm{Ti}-\mathrm{Nb}-\mathrm{Zr}$ with different CPP contents $(5,10,15$, and $20 \mathrm{wt} \%)$ were fabricated by milling for $10 \mathrm{~h}$ and then sintered by SPS technique, which was suitable for hard tissue implant to shun stress 


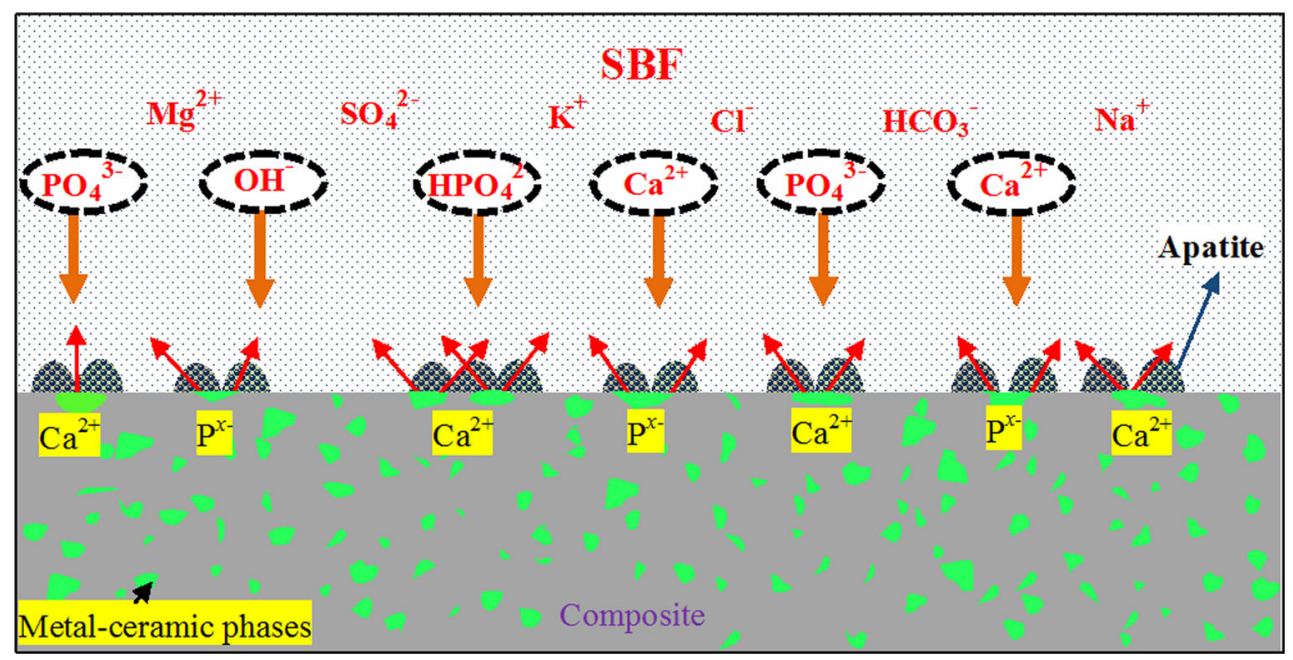

Fig. 11 Schematic mechanism for apatite formation on surface of the composites

shielding and bio-inert. The following conclusions can be drawn:

1. The composites consisted of $\beta$-Ti matrix, $\alpha$-Ti, and reaction products (metal-ceramic phases) such as $\mathrm{CaO}$, $\mathrm{CaTiO}_{3}, \mathrm{CaZrO}_{3}$, and $\mathrm{Ti}_{x} \mathrm{P}_{y}$ when $\mathrm{CPP}$ was added.

2. More CPP addition introduced more holes and finer grains. When the CPP content exceeded $10 \mathrm{wt} \%$, the metal-ceramic phases grew in the $\mathrm{Ti}$ matrix and formed net-like structure, deteriorating the mechanical properties of composites.

3. The compressive elastic modulus of the composites was significantly increased when the CPP was added due to the increasing content of $\alpha$-Ti and metalceramic phases. However, when the CPP content exceeded $10 \mathrm{wt} \%$, the elastic modulus of the sintered composites significantly increased, which could result in stress shielding when used as implant materials.

4. The Ti-35Nb-7Zr-10CPP composite was immersed in $\mathrm{SBF}$, and a dense apatite layer was formed thereon, indicating a better bioactivity than that of $\mathrm{Ti}-35 \mathrm{Nb}-$ $7 \mathrm{Zr}$ alloy without CPP.

Acknowledgments This work was supported by the National Natural Science Foundation of China (No. 31160197), the Innovation Platform Construction Project for Science and Technology, Yunnan Province (No. 2013DH012), and the Analysis and Testing Foundation of Kunming University of Science and Technology (No. 2016T20090120).

\section{References}

[1] A. Biswas, L. Li, U.K. Chatterjee, I. Manna, S.K. Pabi, J. Dutta Majumdar, Scr. Mater. 59, 239 (2008)

[2] M. Long, H.J. Rack, Biomaterials 19, 1621 (1998)
[3] B.Q. Li, X. Lu, Acta Metall. Sin. (Engl. Lett.) 27, 338 (2014)

[4] Y. Okazaki, Y. Ito, K. Kyo, T. Tateishi, Mater. Sci. Eng., A 213, 138 (1996)

[5] Z.M. Li, B.L. Zheng, Y.T. Wang, T. Topping, Y.Z. Zhou, R.Z. Valiev, A.D. Shan, E.J. Lavernia, J. Mater. Sci. 49, 6656 (2014)

[6] A.L.R. Ribeiro, R.C. Junior, F.F. Cardoso, R.B. Fernandes Filho, L.G. Vaz, J. Mater. Sci. Mater. Med. 20, 1629 (2009)

[7] V.A.R. Henriques, E.T. Galvani, S.L.G. Petroni, M.S.M. Paula, T.G. Lemos, J. Mater. Sci. 45, 5844 (2010)

[8] A. Fukuda, M. Takemoto, T. Saito, S. Fujibayashi, M. Neo, S. Yamaguchi, T. Kizuki, T. Matsushita, M. Niinomi, T. Kokubo, T. Nakamura, Acta Biomater. 7, 1379 (2011)

[9] M.A. Baker, S.L. Assis, O.Z. Higa, I. Costa, Acta Biomater. 5, 63 (2009)

[10] J.M. Chaves, O. Florêncio, P.S. Silva Jr., P.W.B. Marques, S.G. Schneider, J. Alloys Compd. 616, 420 (2014)

[11] K.D. Woo, S.H. Park, J.Y. Kim, S.M. Kim, M.H. Lee, Korean J. Mater. Res. 22, 150 (2012)

[12] P.J. Li, I. Kangasniemi, K. de Groot, T. Kokubo, J. Am. Ceram. Soc. 77, 1307 (1994)

[13] X.P. Wang, Y.Y. Chen, L.J. Xu, S.L. Xiao, F.T. Kong, K.D. Woo, J. Mech. Behav. Biomed. Mater. 4, 2074 (2011)

[14] Y.M. Wang, J.Y. Huang, T. Jiao, Y.T. Zhu, A.V. Hamza, J. Mater. Sci. 42, 1751 (2007)

[15] R.A. Nogueira, L.M.C. Pinto, A.C.D. Ângelo, A.P.R.A. Claro, C.R. Grandini, Phys. Rev. B 16, 2746 (2013)

[16] H.S. Kim, T.Y. Ra, I.D. Yeo, H.J. Bang, Y.G. Yoo, W.Y. Kim, J. Mater. Sci. Technol. 24, 33 (2008)

[17] Z. Evis, M. Usta, I. Kutbay, Mater. Chem. Phys. 110, 68 (2008)

[18] P.J. Li, J. Biomed. Mater. Res. A 66, 79 (2003)

[19] A. Arifin, A.B. Sulong, N. Muhamad, J. Syarif, M.I. Ramli, Mater. Des. 65, 1028 (2015)

[20] C.Q. Ning, Y. Zhou, Acta Biomater. 4, 1944 (2008)

[21] H.Z. Ye, X.Y. Liu, H.P. Hong, J. Mater. Sci. Technol. 29, 523 (2013)

[22] Q. Chang, H.Q. Ru, D.L. Chen, X.Y. Yue, L. Yu, C.P. Zhang, J. Mater. Sci. Technol. 27, 546 (2011)

[23] H.T. Anawati, H. Asoh, T. Ohno, M. Kubota, S. Ono, Corros. Sci. 70, 212 (2013)

[24] M. Yousefpour, A. Afshar, J.Y. Chen, X.D. Zhang, Mater. Des. 28, 2154 (2007) 